\title{
Use of Soybean, Corn and Palm Biodiesel in a Centrifugal Pump Driven by a Diesel Engine: Performance and Emissions Analysis
}

\author{
Roberto Guimarães Pereira ${ }^{1}$, \\ João Pedro Barbedo Marques Gutierrez², \\ Juan Manuel Pardal' ${ }^{3}$, Ivenio Moreira da Silva ${ }^{4}$
}

\author{
${ }^{1}$ Fluminense Federal University, TEM/PGMEC/MSG/PGEB, Rua Passo da Pátria 156, CEP 24210-240, Niterói - \\ RJ, Brazil \\ ${ }^{2}$ Fluminense Federal University, PGMEC, Rua Passo da Pátria, 156, CEP: 24210-240, Niterói, RJ, Brazil \\ ${ }^{3}$ Fluminense Federal University, TEM/PGMEC, Rua Passo da Pátria, 156, CEP: 24210-240, Niterói, RJ, Brazil \\ ${ }^{4}$ Fluminense Federal University, TER, Rua Passo da Pátria, 156, CEP: 24210-240, Niterói, RJ, Brazil
}

\begin{abstract}
The present study is related with the use of soybean, corn and palm biodiesel in a centrifugal pump driven by a diesel engine. Performance and emissions analysis were investigated using pure biodiesel (B100) and its mixtures with diesel (B50), comparing the results with pure diesel (B0) and also with the diesel sold at Brazilian fuel stations (B8). A test bench has been optimized for monitoring the behavior of centrifugal pump driven by a diesel engine. The viscosity, density, sulfur tenor, carbon tenor, hydrogen tenor, nitrogen tenor, lower and higher heating value were determined for various fuels used. The power, the fuel consumption and the emissions of: $\mathrm{CO}$; $\mathrm{CO}_{2}$; $\mathrm{NO} ; \mathrm{NO}_{2} ; \mathrm{NO}_{x}$; and $\mathrm{SO}_{2}$ were determined. The engine performed well with biofuels blended (B50) and biodiesels (B100). This confirms one of the great advantages of using biodiesel, which is the possibility of using a renewable fuel produced from a variety of raw materials leading to a cleaner energy production.
\end{abstract}

Keywords: Biodiesel, Centrifugal Pump, Energy, Cleaner Production, Sustainability

\section{Introduction}

The energetics alternatives derived from biomass emerges as considerable options for replace fossil fuels. In this sense, biodiesel is an alternative to substitute the diesel, having similar characteristics in order to be used in conventional engines [1-7]. A recent review about the use of biodiesel in diesel engines can be found in Agarwal et al. [8].

Festel et al. [9] investigated the future evolution of biofuel production costs' in Europe considering the effects of the technological learning and production scale.

Solaimuthu et al. [10] have studied emission reductions of using biodiesel in engine to be used in agricultural operations.

Singh and Rastogi [11] investigated the performance of an engine using biodiesel to be used in irrigation. Experimental analysis of engine performance indicates that the low-level blends of biodiesel (B20 and less) does not requires modifications of the engine.

Compression ignition engines can be used in various steps in agribusiness chain. On a farm, diesel engines enable activities both in fixed locations and in other situations that require mobility.

The supply of water for irrigation takes place, especially with the use of centrifuges pumps that can be triggered either by electric motors or by Otto cycle motors or Diesel cycle motors. Generally, the pump is installed in an area near the water reservoir avoiding problems in the suction system. Sometimes, the costs to adapt the electrical network can unfeasible the project. An appropriate alternative is to trigger the system by means of a diesel engine, which provides mobility and can operate in more than one location serviced by other reservoirs.

The irrigation of cultivated areas can be seen in many regions as unfeasible by the high cost of equipment and limitations on availability of electric energy. However, it is possible to choose an irrigation system using pumps coupled to diesel engines. This system can be used in water supply for irrigation and for various other applications in farms or rural communities. The demands to be met vary from small areas to those that include major extensions.

Thus, the purpose of this research was to obtain biodiesel through oil extracted from seeds of

This article is published under the terms of the Creative Commons Attribution License 4.0

Author(s) retain the copyright of this article. Publication rights with Alkhaer Publications.

Published at: http://www.ijsciences.com/pub/issue/2019-05/

DOI: 10.18483/ijSci.2066; Online ISSN: 2305-3925; Print ISSN: 2410-4477 
soybean, corn and palm, prepare the mixtures of biodiesel with diesel, use them in a centrifugal pump driven by a diesel engine and realize performance and emissions analysis in a test bench.

\section{Raw material for vegetable oil and biodiesel production}

Brazil is a privileged country presenting large arable land area and wide variety of oil believed to be potential sources of convertible vegetable oils into biodiesel. In the country there are, for example the production of: soybean; corn; palm; castor; cotton; sunflower; peanuts and canola, in addition to jatropha curcas, babussu and macaúba.

\subsection{Soybean}

Soybean (Glycine max (L.) Merrill) is widely used in food industry, being also used for biodiesel production, having about $25 \%$ of oil content in grain. United States of America, Brazil, Argentina, India and China are the largest producers in the world.

In 2016, the world production of soybean was around $335 \times 10^{6} \mathrm{t}$ in a harvested area of $122 \times 10^{6}$ ha corresponding a yield of $2.7 \mathrm{t} \cdot \mathrm{ha}^{-1}[12]$.

Brazil, in 2016, was: the second country in soybean production with $96296714 \mathrm{t}$; the second country in harvested area with 33153679 ha and the thirteenth country in yield with 2.9046 t.ha $^{-1}$ [12]. Tables 1,2 and 3 show the top 10 countries, in 2016, in soybean production, area harvested and yield respectively. As we can see, the bigger soybean producers do not have the highest yield.

\subsection{Corn}

Corn (Zea mays L.), also called maize, is a cereal plant of the grass family (Poaceae), been used as: livestock feed; human food and raw material for biodiesel. Corn oil content range from $3.1 \%$ to $5.3 \%$ [13]

In 2016, the world production of corn was around $1060 \times 10^{6} \mathrm{t}$ in a harvested area of $188 \times 10^{6}$ ha corresponding a yield of 5.6 t.ha ${ }^{-1}$ [12].

Brazil, in 2016, was: the third country in corn production with $64143414 \mathrm{t}$; the third country in harvested area with 14958862 ha and the 71th country in yield with 4.2880 t.ha $^{-1}$ [12]. Tables 4, 5 and 6 show the top 10 countries, in 2016, in corn production, area harvested and yield respectively. As we can see, the bigger corn producers do not have the highest yield.

\subsection{Oil Palm}

The oil palm (Elaeis guineensis) is a monocotyledonous tree belonging to the coccoid group of palms. It grows over a period of years to a height of up to $15 \mathrm{~m}$ over a lifetime of 100 years or more. Its productive commercial life is between 20 and 30 years, after which harvesting becomes increasingly difficult, and yields decline slowly.

The palm fruit grows in bunches weighing 10-20 kg. Oil palm is the highest yielding oil crop, producing on average about 4-5 tons of oil/ha/year, about 10 times the yield of soybean oil [14]. The oil content in the mesocarp is $54.7 \%$ [15].

Estimates of oil extractable from fruit bunches vary, being about 4.9 tons of oil/ha/year [16].

In 2016, the oil palm fruit world production was $300 \times 10^{6} \mathrm{t}$ in a harvested area of $21 \times 10^{6}$ ha corresponding a yield of 14.2 t.ha $^{-1}$ [12].

Brazil, in 2016, was: the thirteen country in oil palm fruit production with $1647417 \mathrm{t}$; the fifteenth country in harvested area with 142246 ha and the 22th country in yield with 11.5815 t.ha $^{-1}$ [12]. Tables 7,8 and 9 show the top 10 countries in 2016 in oil palm fruit production, area harvested and yield respectively. As we can see, the bigger oil palm fruit producers do not have the highest yield.

\section{Biodiesel background}

Due to the problems related to shortages and environmental damage generated by the use of fossil fuels and the impossibility of direct use of vegetable oils in conventional engines, researchers have invested resources in finding some alternatives. Biodiesel has been used in many countries [3-5, 7 , 17-23]. Biodiesel can be obtained from: oil crops; animal fats and algae oil. It can also be obtained from nonedible sources such as Jatropha and Karanja oil seeds $[24,25]$ and from recycled waste vegetable oil [26-29 waste]. Researches have been carried about the usage of nanoparticles as additives in biodiesel diesel blends [30, 31].

To produce biodiesel, the transesterification process is used. In the reaction, alcohol in excess is used, as this reduces time and increases the conversion efficiency of the process [32]. $\mathrm{NaOH}$ and $\mathrm{KOH}$ are the catalysts commonly used in the transesterification process. The reaction products are biodiesel (ester) and crude glycerin. A decanting or centrifuging process can be used to separate the biodiesel from glycerin. Pereira et al. [3] shows more details about the process.

In Brazil the regulations for biodiesel is set by the National Agency of Petroleum, Natural Gas and Biofuels (ANP) resolution No. 45 from 25.08.2014.

According to ANP, the Brazilian production of biodiesel in August 2018 reached $486156 \mathrm{~m}^{3}$ and the main raw materials for biodiesel production were soybean oil $(74.14 \%)$ and beef tallow $(11.80 \%)$. The total production of biodiesel in Brazil in 2017 was $4289856 \mathrm{~m}^{3}$ [33]. 
In Brazil, biodiesel must comply with ANP quality specifications in its Resolution No. 45 of 25.08.2014. The percentage of biodiesel mixed with diesel is indicated by the number after letter B. Federal Law $11,097 / 2005$ that introduced biodiesel determined consecutive increases in the blend with diesel, delegating authority to the ANP to regulate and supervise the commercialization of biofuels. Currently, the percentage is $10 \%$ (B10) started in March 2018, according to the text of Law 13,263 of 23.03. 2016.

\section{Material and Methods}

\subsection{Obtaining and production of fuels}

The pure diesel (B0) was obtained through a donation made by Distribuidora Ipiranga S/A. This diesel was also the fuel used to produce the B50 mixtures (50\% in volume diesel and 50\% in volume biodiesel). The B8 fuel ( $92 \%$ in volume diesel and $8 \%$ in volume biodiesel) was acquired from a regular Brazilian fuel station.

Biodiesel had more than one origin depending on its raw material, but all followed the transesterification process from a basic catalyst. Soybean biodiesel produced following the ethylic route was donated by International Virtual Institute of Global Changes of Rio de Janeiro Federal University (IVIG/UFRJ). The biodiesel from corn, palm and soybean produced by the methylic route were all produced at Fluminense Federal University (UFF) in the Laboratory of PostHarvest Technology and Processing of Agricultural Products (LTPC).

The soybean, corn and palm oil used to produce the biodiesel were obtained at the local market. The biodiesel was made by batching process. It was used the transesterification process with basic catalyst and methanol as alcohol. The process followed the steps: dilution of the catalyst in the alcohol, mixing with the vegetable oil, decantation, separation of the glycerin, washing, drying and filtration.

The process started by adding $60 \mathrm{~mL}$ of $99.8 \% \mathrm{PA}$ methanol in the $500 \mathrm{~mL}$ Erlemeyer flask. Then, $2.0 \mathrm{~g}$ of the catalyst, granulated Sodium Hydroxide $(\mathrm{NaOH})$, was weighed, adding the catalyst to the methanol and mixing by means of a magnetic stirrer until complete dilution, generating a solution of methanol $+\mathrm{NaOH}$. Meanwhile, $200 \mathrm{~mL}$ of vegetable oil was transferred to a $500 \mathrm{~mL}$ Becker. This Becker was taken to a greenhouse and heated to a temperature of $60^{\circ} \mathrm{C}$. After this, the vegetable oil was gradually added to the solution (methanol $+\mathrm{NaOH}$ )

The mixture remained on the magnetic stirrer for 60 minutes at $60^{\circ} \mathrm{C}$. At the end of this process, the mixture was transferred to a $500 \mathrm{~mL}$ settling funnel where it remained $24 \mathrm{~h}$ to make the glycerin separation. After the glycerin separation, three washing procedure was done to remove glycerin, methanol and catalyst residues that are still mixed with biodiesel. For the washing, a solution of deionized water with hydrochloric acid PA in a concentration of $0.5 \%$ was added to the biodiesel. After the washing, the biodiesel was removed from the settling funnel and passed to a $500 \mathrm{~mL}$ Becker. It is then taken to the oven at $105^{\circ} \mathrm{C}$ for $2 \mathrm{~h}$ to remove water residue. The biodiesel was then filtered with a paper filter and stored in $1 \mathrm{~L}$ amber glass bottles to be characterized, mixed with diesel and used in the performance tests in a centrifugal pump driven by a diesel engine.

Nine different fuels were used in the tests: (i) ethyl soybean biodiesel (B100); (ii) methyl soybean biodiesel (B100); (iii) methyl corn biodiesel (B100); (iv) methyl palm biodiesel (B100); (v) 50\% vol. methyl soybean biodiesel $+50 \%$ vol. diesel (B50); (vi) $50 \%$ vol. methyl corn biodiesel $+50 \%$ vol. diesel (B50); (vii) $50 \%$ vol. methyl palm biodiesel $+50 \%$ vol. diesel (B50); (viii) $8 \%$ vol. biodiesel $+82 \%$ vol. diesel (B8 - fuel commercialized at Brazilian fuel stations) and (ix) diesel (B0).

\subsection{Fuels characterization}

The dynamic and kinematic viscosity and the density of the biodiesels (B100) were determined.

The density $(\rho)$ was obtained through the use of a pycnometer, based on the NIE_DIMEL-039 standard of the National Institute of Metrology, Quality and Technology (INMETRO). To determine the density, 3 replicates were made.

The dynamic viscosity $(\eta)$ was obtained through the use of a HAAKE RS 50 rheometer, with temperature control through a thermostatic bath.

The kinematic viscosity ( $v$ ) was determined dividing the dynamic viscosity by the density.

For the fuels: B8 (fuel commercialized at Brazilian fuel stations); B100 methyl soybean biodiesel; B100 ethyl soybean biodiesel; B50 methyl soybean biodiesel and B50 ethyl soybean biodiesel the following properties were determined: sulfur tenor (ASTM D5453-16); carbon tenor (ASTM D529116); hydrogen tenor (ASTM D5291-16); nitrogen tenor (ASTM D5291-16); lower heating value (ASTM D4809-13) and higher heating value (ASTM D4809-13)

\subsection{Test bench characteristics}

To carry out the tests a bench was used consisting of a centrifugal pump driven by a diesel engine that circulates the water in a closed circuit with a reservoir raised to $3 \mathrm{~m}$ from the centrifugal pump (Figure 1). This circuit is installed in a test room at Fluminense Federal University.

The diesel engine used has the following characteristics: Lintec manufacturer; 3300 rpm 
higher speed; four-stroke; direct injection; one cylinder; air cooling system; $0.211 \mathrm{~L}$ displacement volume; $2.8 \mathrm{~kW}$ maximum output; $2.5 \mathrm{~L}$ fuel capacity and $32 \mathrm{~kg}$ weight. The centrifugal pump has the following characteristics: Lintec manufacturer; $36 \mathrm{~m}^{3} / \mathrm{h}$ maximum flow rate; $26 \mathrm{~m}$ maximum head; 8 $\mathrm{m}$ maximum suction head

The test bench allows to obtain the following parameters: temperature; pressure and flow rate at pump suction; pump discharge and after the globe valve that causing change in load and flow rate.

In addition to the temperature, pressure and flow sensors, the test bench includes two scales to control consumption. One scale is dedicated to the fuel tank and the other to the return, the total consumption is given by the difference between the two values.

The engine rotation was obtained using a tachometer (Minipa MDT-2238A model).

More details about the test bench are available at Gutierrez [34].

\subsection{Performance and consumption analysis}

For the analysis of the performance and consumption of centrifugal pump driven by a diesel engine, two types of tests were made.

The first consists of a variation of the engine rotation, in which the valve of the system was fixed in a predefined position (the maximum one) and the rotations were varied through the engine accelerator. Five rotations were chosen to make parameters acquisitions: 2200; 2500; 2800; 3100 and $3300 \mathrm{rpm}$

The second test consists of increasing the load for the same rotation, fixing the rotation $(3100 \mathrm{rpm})$ and varying the valve position. Five valve position were chosen to make parameters acquisitions, corresponding to the flow rates: $9.5 ; 10.5 ; 11.5 ; 12$ and $13 \mathrm{~m}^{3} \cdot \mathrm{h}^{-1}$

\subsection{Gas emissions analysis}

It was used the gas analyzer Testo $350 \mathrm{XL}$ in order to measure the emissions. The resolution and the error limits of the Testo $350 \mathrm{XL}$ for measured gases are: $\mathrm{CO}, 1 \mathrm{ppm}$ and $\pm 5 \mathrm{ppm} ; \mathrm{CO}_{2}, 0.01 \%$ and $\pm 0.3 \%$; $\mathrm{NO}, 1 \mathrm{ppm}$ and $\pm 5 \mathrm{ppm} ; \mathrm{NO}_{2}, 0.1 \mathrm{ppm}$ and $\pm 5 \mathrm{ppm}$, calculated $\mathrm{NO}_{\mathrm{x}}, 1 \mathrm{ppm} ; \mathrm{SO}_{2}, 1 \mathrm{ppm}$ and $\pm 5 \mathrm{ppm}$.

\section{Results and Discussion}

\subsection{Fuels characterization}

Table 10 shows the values of the: density; dynamic viscosity and kinematic viscosity of the biodiesels (B100) used in the tests.

The biodiesels density was kept inside the limits established by ANP (850-900 kg.m ${ }^{-3}$ at $\left.20^{\circ} \mathrm{C}\right)$, as shown in Table 10.
According Table 10, the kinematic viscosity of the biodiesels was kept inside the limits established by ANP $\left(3-6 \mathrm{~mm}^{2} \cdot \mathrm{s}^{-1}\right.$ at $\left.40^{0} \mathrm{C}\right)$. The soybean biodiesel that used the methyl route as the process was the one with the lowest viscosity, while soybean biodiesel that used the ethanol route had the highest viscosity.

The viscosity has a very important characteristic for fuels. Viscosity influences lubrication and fuel flow to the combustion chamber. As the viscosity acquisition at $40^{\circ} \mathrm{C}$ was done through the rheometer RS50, it was possible to obtain the flow curve (Figure 2). In this way it is possible to observe that the behavior of the biodiesels (B100) and diesel (B0) analyzed is of a Newtonian fluid, as was expected for these fuels. We can say this by the shape of the generated curve, where it is shown that the relationship between the stress and the shear rate is a straight line that has its origin at zero. As the dynamic viscosity is the tangent of this line, it is possible to note that this viscosity is higher in biodiesels than in the diesel. Also, it is observed that even biofuels having differences between them, they are much smaller than the difference for diesel, which has a lower dynamic viscosity than all biodiesels analyzed.

The behavior in which the viscosity is higher in biodiesels than in the diesel was reported by Geller et al. [35]; Souza et al. [36] and Mejia et al.[37].

Table 11 shows the values of: sulfur tenor; carbon tenor; hydrogen tenor; nitrogen tenor; lower heating value and higher heating value for the fuels: B8 (fuel commercialized at Brazilian fuel stations); B100 methyl soybean biodiesel; B100 ethyl soybean biodiesel; B50 methyl soybean biodiesel and B50 ethyl soybean biodiesel.

As shown in Table 11 the tenor of sulfur, carbon, hydrogen and nitrogen and the lower and higher heating values decrease as the biodiesel percentage increases. Concerning environmental questions, it is an advantage of using fuels with lower tenor of sulfur, carbon and nitrogen. With respect to lower heating value, it is observed a maximum reduction of $12.46 \%$ (in the case of B100 ethyl soybean biodiesel) compared with the B8 fuel, that not affected significantly the performance of the engine as will be discussed later.

\subsection{Performance and consumption analysis 5.2.1 Volumetric consumption}

By analyzing the fuel consumption in liters per hour for the engine speed variation (Figures 3 and 4), given the total volume consumed by the engine, a consistent behavior is observed as the increase in rotation is reflected in an increase in consumption. This is a natural tendency, taking into account the consumption of biodiesels and their mixtures all have a higher volumetric consumption than diesel. 
As shown in Figures 3 and 4 the diesel (B0) has the lowest consumption and the B8 fuel has a consumption slightly superior to the one of the diesel.

According Figure 3, the behavior of the B50 mixtures of biodiesels is similar. In the use of the B50 fuels, in comparison with the diesel, the volumetric consumptions that presented closer values were obtained at $2800 \mathrm{rpm}$ (maximum difference of $5 \%$ ). In the case of B50 biodiesels, the lowest difference in consumption compared with diesel was the B50 methyl corn biodiesel, with a difference of $0.26 \%$ at $2800 \mathrm{rpm}$. The worst result was observed with the B50 ethyl soybean biodiesel with a consumption $19.40 \%$ higher than diesel one at $2500 \mathrm{rpm}$.

Figure 4 shows the behavior of the biodiesels compared with $\mathrm{B} 8$ and $\mathrm{B} 0$. The best performance among the biodiesels was presented by B100 methyl soybean biodiesel with a difference of $2.65 \%$ at 3300 rpm, compared with the diesel case. The worst result was observed with the B100 ethyl soybean where it had a consumption of $18.18 \%$ higher than diesel one at $2500 \mathrm{rpm}$.

\subsubsection{Specific consumption}

When analyzing the performance of the engine through the specific consumption, it is observed a decrease in specific consumption as the engine speed increased (Figures 5 and 6).

The specific consumption is a very important information in the evaluation of an engine. This data evaluates the performance of the motor (the relation between consumption and the power generated). Therefore, it is not strange that consumption per liter has given an upward curve for all fuels while specific consumption has shown a downward curve. This curve allows us to better evaluate the performance of the engine, since as important as the consumption is the power generated. It can be observed that the B8 performance was very similar to that of the diesel that has the best performance.

According Figure 5 the specific consumption of the B50 mixtures are quite similar at higher engine speeds. This shows that we can use different B50 mixtures in the daily use of this type of equipment, considering that these motors usually operate in the upper range of rotations.

The B50 methyl soybean biodiesel presented the higher specific consumption at low engine speed (1.5 g. $W^{-1} \cdot h^{-1}$ at $\left.2200 \mathrm{rpm}\right)$.

In the case of soybean biodiesel produced from different alcohols, it is shown in Fig. 6 that the B100 methyl soybean biodiesel has the lower specific consumption. This difference is more accentuated at low engine speed. At maximum engine speed, the B100 ethyl soybean biodiesel and the B100 methyl soybean biodiesel have practically the same behavior.

According Fig. 6, the B100 methyl palm biodiesel presented the lower specific consumption compared with others biodiesels.

Figure 6 shows that the specific consumption of the biodiesels produced from different raw materials are quite similar at higher engine speeds.

When we compare the specific consumption and performance of the engine with others researches developed in the same engine [38, 39] we see a similar behavior regarding the consumption and performance of the biodiesels (B100) and mixtures of $\mathrm{B} 50$, that presented performance slightly inferior than that of diesel.

Figures 7 and 8 show the specific consumption for different flow rate of $\mathrm{B} 50$ mixtures, $\mathrm{B} 100$ and diesel (B0). The diesel presented the lower specific consumption for all flow rate investigated. For all fuels tested, the specific consumption decreases at the flow rate increases, achieving practically a constant value for flow rates greater than $12 \mathrm{~m}^{3} \cdot \mathrm{h}^{-1}$. The lower specific consumption at higher flow rates it is interesting for maximum irrigation purposes.

\subsubsection{Power}

Figures 9 and 10 show the power for different flow rate of B50 mixtures, B100 and diesel (B0). The power curve has an inverted behavior to that of the specific consumption when the position of the valve has been varied, being observed an increase in the power as the flow rate increases.

More power is need in order to achieve higher flow rates corresponding a situation of maximum irrigation.

At maximum flow rate $\left(13 \mathrm{~m}^{3} \cdot \mathrm{h}^{-1}\right)$, the lower power occurs with B100 methyl palm biodiesel $(389.82 \mathrm{~W})$ and with B50 methyl corn biodiesel $(389.81 \mathrm{~W})$. But the maximum difference in power at the maximum flow rate for the B50 mixtures is $3.62 \%$ and for the biodiesels (B100) is $3.87 \%$, indicating that the different biodiesels can be use in the engine without significant loss of the performance.

\subsection{Gas emission analysis}

Figures 11 to 16 show the results for the gas emission analysis $\left(\mathrm{SO}_{2}, \mathrm{NO}, \mathrm{NO}_{2}, \mathrm{NO}_{\mathrm{x}}, \mathrm{CO}, \mathrm{CO}_{2}\right)$ of the engine operating with the fuels: B8; B50 and B100.

In the analysis of $\mathrm{SO}_{2}$ emission (Figure 11), it can be observed that there is a reduction in the amount of $\mathrm{SO}_{2}$ when the biodiesel percentage increases. The reduction in $\mathrm{SO}_{2}$ emissions is favorable concerning the environment and health. The $\mathrm{SO}_{2}$ emissions reduction with diesel-biodiesel blends was reported in the literature $[1-5,40,41]$. 
$\mathrm{SO}_{2}$ is a pollutant that causes respiratory irritation and can cause asthma attacks in asthmatic subjects. In the atmosphere, it oxidises to become sulphuric acid (a component of acid rain) [42].

Figures 12 to 14 show the emissions of $\mathrm{NO}, \mathrm{NO}_{2}$ and $\mathrm{NO}_{\mathrm{x}}$ that in general increases as the biodiesel percentage increases. Burning biodiesel produces nitrogen oxides because the high oxygen content although it promotes combustion efficiency and reduces emissions of other pollutants [43]. Other factors, such as: biodiesel physicochemical properties, fuel spray characteristics, engine type and operation conditions can also affect the $\mathrm{NO}_{\mathrm{x}}$ emission [44].

Concerning the $\mathrm{NO}_{2}$ emissions, it can be observed (Figure13) that the B50 methyl corn biodiesel and B50 methyl soybean biodiesel presented the lower emission, $57 \mathrm{ppm}$ and $58 \mathrm{ppm}$, respectively.

It can be observed that concerning the $\mathrm{NO}_{\mathrm{x}}$ emissions (Figure 14) the B100 methyl corn biodiesel and B100 methyl soybean biodiesel had the worst results, 172 ppm and $180 \mathrm{ppm}$, respectively. In the case of B100 methyl corn biodiesel, there was a difference of $9.9 \%$ compared with B8 fuel, while in B100 methyl soybean biodiesel the difference increased to $13.9 \%$. The emissions of B50 methyl corn biodiesel; B50 ethyl soybean biodiesel and B50 methyl soybean biodiesel are quite similar to emission of B8. In the case of the biodiesels, the B100 methyl palm biodiesel had the lowest $\mathrm{NO}_{\mathrm{x}}$ emission (166 ppm)

$\mathrm{NO}_{2}$ is a pollutant that causes respiratory irritation and in asthmatic subjects can causes a decrease in lung function. In the atmosphere, $\mathrm{NO}_{\mathrm{x}}$ oxidises to become nitric acid (a component of acid rain) [40].

Figures 15 and 16 show the $\mathrm{CO}$ and $\mathrm{CO}_{2}$ emissions. The emissions of $\mathrm{CO}_{2}$ are greater in $\mathrm{B} 100$ fuels than $\mathrm{B} 50$ and $\mathrm{B} 8$ fuels indicating a more complete combustion, resulting in general in less emission of CO. The biodiesels are esters having oxygen in their chain, which in the reaction is added to the oxygen present in the air, thus influencing the resulting stoichiometric ratios. The B50 methyl corn biodiesel has the lower $\mathrm{CO}_{2}$ emission (3.6\%) and the $\mathrm{B} 100$ methyl palm biodiesel has the lower $\mathrm{CO}$ emission (790 ppm).

$\mathrm{CO}$ is a pollutant that is very toxic at high concentrations. It can cause headaches, nausea, and even death. In the atmosphere, it oxidises to become $\mathrm{CO}_{2}$ (a greenhouse effect gas) [42].

\section{Conclusions}

Biodiesel has grown in the world scenario and is confirmed as a good and fast option for reducing the use of petroleum products leading to a cleaner energy production, besides can be obtained from a great variety of raw materials.

In the case of agricultural irrigation purposes, biodiesel and diesel-biodiesel blends used as fuels in centrifugal pump driven by a diesel engine are sustainable options mainly in regions without electricity.

The B100 methyl palm biodiesel presented the lower specific consumption compared with others biodiesels. But at higher engine speeds the specific consumption of the biodiesels produced from different raw materials are quite similar. At higher flow rates the specific consumption is lower that is interesting for maximum irrigation purposes.

The difference in power for the B50 mixtures and the biodiesels (B100) is less than $3.9 \%$, indicating that the different biodiesels can be use in the engine without significant loss of the performance.

A reduction in $\mathrm{SO}_{2}$ emissions occurs when the percentage of biodiesel increases. The reduction in $\mathrm{SO}_{2}$ emissions is favorable concerning the environment and health.

In general the lower emissions of $\mathrm{CO}$ are obtained using biodiesels (B100) as fuels. It is an advantage, concerning that $\mathrm{CO}$ is very toxic at high concentrations.

\section{Acknowledgments}

The author Roberto G. Pereira is grateful to $\mathrm{CNPq}$ (National Research Council of Brazil) for the financial support.

\section{References}

1. Pereira, R. G., Tulcán, O. E. P., Fellows, C. E., 2017. Engine Performance: Biofuels versus Petrofuels. In: M. R. Riazi; David Chiaramonti. (Org.). Biofuels Production and Processing Technology. 1ed.: CRC Press Taylor \& Francis Group, pp. 569-586.

2. Pereira, R. G., Tulcán, O. E. P., Fellows, C. E., Braz, A. J. L., 2017. "Energy Generation and Exhaust Emissions Analysis in a Stationary Engine Using Palm Biodiesel, Palm Oil and Diesel". International Journal of Oil Gas and Coal Technology 16, 402-421.

3. Pereira R.G., Tulcan O.E.P., Fellows C.E., Silva I.M., Santo Filho D.M.E., Lameira V.J, Quelhas O.L.G., 2014. "Energy generation using coconut biodiesel and coconut oil in a stationary engine", Int J Oil Gas and Coal Technology 7 (4), 450-473.

4. Pereira R.G., Tulcan O.E.P., Fellows C.E., Lameira V.J., Quelhas O.L.G., Aguiar M.E., Santo Filho D.M.E., 2012. "Sustainability and mitigation of greenhouse gases using ethyl beef tallow biodiesel in energy generation", J. Clean. Prod. 29-30, 269-276.

5. Pereira R.G., Oliveira C.D., Oliveira J.L., Oliveira P.C.P., Fellows C.E., Piamba O.E., 2007. "Exhaust emissions and electric energy generation in a stationary engine using blends of diesel and soybean biodiesel". Renewable Energy 32 (14), 2453-2460.

6. Atabani, A.E., Mofijur, M., Masjuki, H.H., Badruddin, I.A. Chong, W.T., Cheng, S.F., Gouk, S.W., 2014. "A study of production and characterization of Manketti (Ricinodendron rautonemii) methyl ester and its blends as a potential biodiesel feedstock". Biofuel Research Journal 4, 139-146

7. Demirbas, A., 2009." Biofuels securing the planet's future 
energy needs". Energy Conversion and Management 50 (9), 2239-2249.

8. Agarwal, A.K.,, Park,S., Dhar, A., Lee, C.S, Park, S., Gupta, T. and Gupta, N.K., 2018, "Review of Experimental and Computational Studies on Spray, Combustion, Performance, and Emission Characteristics of Biodiesel Fueled Engines", J. Energy Resour. Technol 140(12), p. 120801

9. Festel, G., Würmseher, M., Rammer, C., Boles, E., Bellof, M., 2014. "Modelling production cost scenarios for biofuels and fossil Fuels in Europe". J. Clean. Prod. 66, 242 - 253.

10. Solaimuthu, C., Ganesan, V., Senthilkumar, D., Ramasamy, K.K., 2015. "Emission reductions studies of a biodiesel engine using EGR and SCR for agriculture operations in developing countries", Applied Energy 138, 91-98

11. Singh, I., Rastogi, V., 2009. "Performance analysis of a modified 4-stroke engine using biodiesel fuel for irrigation purpose". International Journal of Applied Environmental Sciences 4 (2) 229-242.

12. FAO (2018) Food and Agriculture Organization of the United Nations. http://www.fao.org/faostat/en/\#data/QC (accessed 10 September 2018).

13. Fassio, A.S., Restaino, E.A., Cozzolino, D., 2015. "Determination of oil content in whole corn (Zea mays L.) seeds by means of near infrared reflectance spectroscopy", Computers and Electronics in Agriculture 110, 171-175

14. Sumathi, S., Chai, S.P., Mohamed, A.R., 2008. "Utilization of oil palm as a source of renewable energy in Malaysia". Renewable and Sustainable Energy Reviews 12 (9), 24042421.

15. Cadena, T., Prada, F., Perea, A., Romero, H.M., 2013. "Lipase activity, mesocarp oil content, and iodine value in oil palm fruits of Elaeis guineensis, Elaeis oleifera, and the interspecific hybrid $\mathrm{O} \times \mathrm{G}(\mathrm{E}$. oleifera $\times \mathrm{E}$. guineensis)", J Sci Food Agric., 93(3), 674-680.

16. Reijnders, L., Huijbregts, M.A.J., 2008. "Palm oil and the emission of carbon-based greenhouse Gases". J. Clean. Prod. 16 (4) 477-482.

17. Pereira, R.G., Tulcan, O.E.P., Lameira, V.J., Santo Filho, D.M.E., Andrade, E.T., 2011. Use of soybean oil in energy generation, in Krezhova, D. (Ed.): Recent Trends for Enhancing the Diversity and Quality of Soybean Products. 301-320, InTech Publishing, Rijeka, Croatia.

18. Nautiyal, P., Subramanian, K.A.. Dastidar, M.G. 2014. "Production and characterization of biodiesel from algae". Fuel Processing Technology 120, 79-88.

19. Giwa, S.O., Chuah, L.A., Adam, N.M. 2014. "Fuel properties and rheological behavior of biodiesel from egusi (Colocynthis citrullus L.) seed kernel oil". Fuel Processing Technology 122, 42-48.

20. Gülüm, M., Bilgin, A. 2015. "Density, flash point and heating value variations of corn oil biodiesel-diesel fuel blends". Fuel Processing Technology 134, 456-464.

21. Almeida, V.F., García-Moreno, P.J., Guadix, A. and Guadix, E.M. 2015. "Biodiesel production from mixtures of waste fish oil, palm oil and waste frying oil: optimization of fuel properties". Fuel Processing Technology 133, 152-160.

22. Öztürk, E. 2015. "Performance, emissions, combustion and injection characteristics of a diesel engine fuelled with canola oil-hazelnut soapstock biodiesel mixture". Fuel Processing Technology 129, 183-191.

23. Ketlogetswe, C, Gandure, J., Jonas, M,, 2018, “ On-road Performance Analysis of Tallow Biodiesel on a 2.8 Toyota Raider Hilux", International Journal of Sciences, DOI: 10.18483/ijSci. 1541

24. Mistri, G.K., Aggarwal, S.K., Longman, D., Agarwal, A.K., 2015, "Performance and Emission Investigations of Jatropha and Karanja Biodiesels in a Single-Cylinder CompressionIgnition Engine Using Endoscopic Imaging", J. Energy Resour. Technol 138(1), 011202-13

25. Patel, C., Hwang, J., Chandra, K., Agarwal, R.A., Bae, C., Gupta, T., Agarwal, A.K., 2018, “ In-Cylinder Spray and Combustion Investigations in a Heavy-Duty Optical Engine Fueled With Waste Cooking Oil, Jatropha, and Karanja Biodiesels", J. Energy Resour. Technol 141(1), 012201-12
26. Singh, B., Kaur, J., Singh, K., 2010, "Production of Biodiesel From Used Mustard Oil and Its Performance Analysis in Internal Combustion Engine", J. Energy Resour. Technol 132(3), 031001-4

27. Chokri, B., Ridha, E., Rachid, S., Jamel, B., 2012, "Experimental Study of a Diesel Engine Performance Running on Waste Vegetable Oil Biodiesel Blend", J. Energy Resour. Technol 134(3), 032202-6

28. Thushari, P. G. I., Babel, S., 2017, "Biodiesel Production From Waste Palm Oil Using Palm Empty Fruit BunchDerived Novel Carbon Acid Catalyst", J. Energy Resour. Technol 140(3), 032204-10

29. Qasim, M., Ansari,T.M., Hussain,M., 2017, "Preparation, Characterization and Engine Performance of Biodiesel Fuel Derived from Waste Cooking Oil and its Blends", International Journal of Sciences, DOI: 10.18483/ijSci.1231

30. Prabu, A., 2018, Engine Characteristic Studies by Application of Antioxidants and Nanoparticles as Additives in Biodiesel Diesel Blends, J. Energy Resour. Technol 140(8), 082203-7

31. Debbarma, S., Misra, R. D. 2017, "Effects of Iron Nanoparticles Blended Biodiesel on the Performance and Emission Characteristics of a Diesel Engine", J. Energy Resour. Technol 139(4), 042212-8

32. Lang, X., Dalai, A., Bakhshi, N., Reaney, M. and Hertz, P. 2001. "Preparation and characterization of bio-diesels from various bio-oils". Bioresource Technology 80, 53-62.

33. ANP (2018) National Agency of Petroleum, Natural Gas and Biofuels, in Portuguese, http://www.anp.gov.br/dadosestatisticos (accessed 26 November 2018).

34. Gutierrez, J. P. B. M. 2018. Analysis of the performance of a centrifugal pump driven by a diesel engine using biodiesel obtained from soy, corn and palm oils, and mixtures with diesel (in Portuguese). M.Sc. dissertation, Fluminense Federal University.

35. Geller, D.P., Adams, T.T., Goodrum, J.W., Pendergrass J., 2008. "Storage stability of poultry fat and diesel fuel mixtures: Specific gravity and viscosity". Fuel 87, 92-102.

36. Souza C. D. R, Chaar J. S., Souza R. C. R., Jeffreys M. F., Souza K. S., Costa E. J. C., Santos J. C., 2009. "Physicalchemical characterization of biodiesel and diesel binary mixtures marketed in Amazonas" (in Portuguese). Acta Amazônica 39 (2), 383 - 388.

37. Mejia, J.D, Salgado, N., Orrego, C.E. 2013. "Effect of blends of Diesel and Palm-Castor biodiesels on viscosity, cloud point and flash point". Industrial Crops and Products 43, 791- 797.

38. da Silva, I.M. 2014. Energy generation and exergetic analysis in a centrifugal pump driven by a diesel engine using biodiesel produced by transesterification using ultrasound (in Portuguese), Ph.D. thesis. Fluminense Federal University, Niterói, RJ, Brazil.

39. Macedo T. O., 2013. Methodology for experimental exergetic evaluation of a pump driven by a diesel engine, operating with standard diesel and biodiesel (in Portuguese). M.Sc. dissertation, Fluminense Federal University.

40. Usta, N., Ozturk, E., Cam, O., Conkur, E.S., Nas, S., Côn, A.H., Can, A.Ç., Topcu, M., 2005. "Combustion of biodiesel fuel produced from hazelnut soapstock/waste sunflower oil mixture in a diesel engine". Energy Conversion and Management 46, 741-755.

41. Usta, N., 2005. "An experimental study on performance and exhaust emissions of a diesel engine fuelled with tobacco seed oil methyl ester". Energy Conversion and Management 46, 2373-2386.

42. Pénard-Morand, C., Annesi-Maesano, I., 2004. "Air pollution: from sources of emissions to health effects". Breathe. 1 (2), 108-119

43. Lin, C.Y., Lin, H.A., 2008. "Effects of NOx-inhibitor agent on fuel properties of threephase biodiesel emulsions". Fuel Processing Technology 89, 1237-1242.

44. Bakeas, E., Karavalakis, G., Stournas, S., 2011. "Biodiesel emissions profile in modern diesel vehicles. Part 1: effect of biodiesel origin on the criteria emissions". Science of the Total Environment 409, 1670-1676. 
Use of Soybean, Corn and Palm Biodiesel in a Centrifugal Pump Driven by a Diesel Engine: Performance and Emissions Analysis

Table 1 Soybean production in 2016 (top 10)

\begin{tabular}{|c|c|}
\hline Country & Soybean production in $2016(t)$ \\
\hline United States of America & 117208380 \\
\hline Brazil & 96296714 \\
\hline Argentina & 58799258 \\
\hline India & 14008000 \\
\hline China, mainland & 11963244 \\
\hline Paraguay & 9163030 \\
\hline Canada & 5827100 \\
\hline Ukraine & 4276990 \\
\hline Bolivia & 3204639 \\
\hline Russian Federation & 3135177 \\
\hline \multicolumn{2}{|c|}{ Source: http://www.fao.org/faostat/en/\#data/QC (accessed 10.9.2018) } \\
\hline Table 2 & a harvested in 2016 (top 10) \\
\hline Country & Soybean area harvested in 2016 (ha) \\
\hline United States of America & 33482430 \\
\hline Brazil & 33153679 \\
\hline Argentina & 19504648 \\
\hline India & 11500000 \\
\hline China, mainland & 6639113 \\
\hline Paraguay & 3370000 \\
\hline Canada & 2190500 \\
\hline Russian Federation & 2120014 \\
\hline Ukraine & 1859400 \\
\hline Bolivia & 1336399 \\
\hline
\end{tabular}

Source: http://www.fao.org/faostat/en/\#data/QC (accessed 10.9.2018)

Table 3 Soybean yield in 2016 (top 10)

\begin{tabular}{|c|c|}
\hline Country & Soybean yield in $2016\left(\right.$ t.ha $\left.^{-1}\right)$ \\
\hline Turkey & 4.3219 \\
\hline Georgia & 3.7592 \\
\hline Italy & 3.7539 \\
\hline United States of America & 3.5006 \\
\hline Egypt & 3.5000 \\
\hline Serbia & 3.1610 \\
\hline Greece & 3.1112 \\
\hline Croatia & 3.1047 \\
\hline Austria & 3.0648 \\
\hline Argentina & 3.0146 \\
\hline
\end{tabular}

Table 4 Corn production in 2016 (top 10)

\begin{tabular}{lc}
\hline \multicolumn{1}{c}{ Country } & Corn production in 2016 (t) \\
\hline United States of America & 384777890 \\
China, mainland & 231673946 \\
Brazil & 64143414 \\
Argentina & 39792854 \\
Mexico & 28250783 \\
Ukraine & 28074610 \\
India & 26260000 \\
Indonesia & 20369551 \\
Russian Federation & 15309813 \\
Canada & 12349400 \\
\hline
\end{tabular}

Source: http://www.fao.org/faostat/en/\#data/QC (accessed 10.9.2018) 
Use of Soybean, Corn and Palm Biodiesel in a Centrifugal Pump Driven by a Diesel Engine: Performance and Emissions Analysis

Table 5 Corn area harvested in 2016 (top 10)

\begin{tabular}{lc}
\hline \multicolumn{1}{c}{ Country } & Corn area harvested in 2016 (ha) \\
\hline China, mainland & 38952521 \\
United States of America & 35106050 \\
Brazil & 14958862 \\
India & 10200000 \\
Mexico & 7598086 \\
Nigeria & 6544248 \\
Argentina & 5346593 \\
Ukraine & 4252200 \\
United Republic of Tanzania & 4036996 \\
Indonesia & 3792839 \\
\hline Source: http://www fao.org/faostat/en/\#data/QC (accessed 10.9 .2018$)$
\end{tabular}

Source: http://www.fao.org/faostat/en/\#data/QC (accessed 10.9.2018)

Table 6 Corn yield in 2016 (top 10)

\begin{tabular}{lc}
\hline \multicolumn{1}{c}{ Country } & Corn \\
\hline Jordan & 40.4127 \\
United Arab Emirates & 26.1786 \\
Saint Vincent and the Grenadines & (1) \\
Israel & 24.7429 \\
Kuwait & 22.9983 \\
Qatar & 16.7860 \\
Tajikistan & 12.5011 \\
Uzbekistan & 12.3634 \\
Oman & 11.9570 \\
New Zealand & 11.9543 \\
\hline Source: & 11.6893 \\
\hline
\end{tabular}

Source: http://www.fao.org/faostat/en/\#data/QC (accessed 10.9.2018)

Table 7 Oil palm fruit production in 2016 (top 10)

\begin{tabular}{lc}
\hline \multicolumn{1}{c}{ Country } & Oil palm fruit production in 2016 (t) \\
\hline Indonesia & 160135795 \\
Malaysia & 86325309 \\
Thailand & 12081855 \\
Nigeria & 7817207 \\
Colombia & 6762416 \\
Ecuador & 3124069 \\
Cameroon & 2701709 \\
Ghana & 2443000 \\
Papua New Ghinea & 2379738 \\
Guatemala & 2103356 \\
\hline
\end{tabular}

Source: http://www.fao.org/faostat/en/\#data/QC (accessed 10.9.2018)

Table 8 Oil palm fruit area harvested in 2016 (top 10)

\begin{tabular}{|c|c|}
\hline Country & Oil palm fruit area harvested in 2016 (ha) \\
\hline Indonesia & 9333482 \\
\hline Malaysia & 5001438 \\
\hline Nigeria & 3053974 \\
\hline Thailand & 650625 \\
\hline Ghana & 349040 \\
\hline Colombia & 331506 \\
\hline Guinea & 314064 \\
\hline Côte d'Ivoire & 268342 \\
\hline Ecuador & 263839 \\
\hline Democratic Republic of the Congo & 178557 \\
\hline
\end{tabular}


Use of Soybean, Corn and Palm Biodiesel in a Centrifugal Pump Driven by a Diesel Engine: Performance and Emissions Analysis

Table 9 Oil palm fruit yield in 2016 (top 10)

\begin{tabular}{lc}
\hline \multicolumn{1}{c}{ Country } & Oil palm fruit yield in $\mathbf{2 0 1 6}\left(\mathbf{t} . \mathbf{h a}^{\mathbf{1}}\right)$ \\
\hline Colombia & 20.3991 \\
Thailand & 18.5696 \\
Cameroon & 18.5049 \\
Benin & 17.4160 \\
Malaysia & 17.2601 \\
Indonesia & 17.1571 \\
Costa Rica & 15.0360 \\
Guatemala & 14.7088 \\
Solomon Islands & 14.5519 \\
Peru & 14.4220 \\
\hline Source: http://www.fao.org/faostat/en/\#data/QC (accessed 10.9 .2018$)$
\end{tabular}

Table 10 Properties of biodiesels (B100)

\begin{tabular}{lcccc}
\hline Properties & $\begin{array}{c}\text { B100 methyl } \\
\text { soybean } \\
\text { biodiesel }\end{array}$ & $\begin{array}{c}\text { B100 ethyl } \\
\text { soybean } \\
\text { biodiesel }\end{array}$ & $\begin{array}{c}\text { B100 ethyl } \\
\text { palm } \\
\text { biodiesel }\end{array}$ & $\begin{array}{c}\text { B100 ethyl } \\
\text { corn } \\
\text { biodiesel }\end{array}$ \\
\hline $\begin{array}{l}\text { Density at } 20^{0} \mathrm{C} \\
\left(\mathrm{kg} \cdot \mathrm{m}^{-3}\right)\end{array}$ & 880.42 & 878.46 & 872.27 & 873.45 \\
$\begin{array}{l}\text { Density at } 40^{\circ} \mathrm{C} \\
\left(\mathrm{kg} \cdot \mathrm{m}^{-3}\right)\end{array}$ & 868.73 & 873.36 & 861.30 & 861.78 \\
$\begin{array}{l}\text { Dynamic } \\
\text { viscosity at }\end{array}$ & 4.21 & 4.60 & 4.22 & 4.51 \\
$\begin{array}{l}40^{0} \mathrm{C}(\mathrm{mPa} . \mathrm{s}) \\
\text { Knematic } \\
\text { viscosity at }\end{array}$ & 4.85 & 5.27 & & \\
$40^{0} \mathrm{C}\left(\mathrm{mm}^{2} . \mathrm{s}^{-1}\right)$ & & & 4.90 & \\
\hline
\end{tabular}

Table 11 Properties of B8, B50 ethyl and methyl soybean biodiesel, B100 ethyl and methyl soybean biodiesel

\begin{tabular}{lccccc}
\hline Properties & B8 & $\begin{array}{c}\text { B50 methyl } \\
\text { soybean } \\
\text { biodiesel }\end{array}$ & $\begin{array}{c}\text { B100 methyl } \\
\text { soybean } \\
\text { biodiesel }\end{array}$ & $\begin{array}{c}\text { B50 ethyl } \\
\text { soybean } \\
\text { biodiesel }\end{array}$ & $\begin{array}{c}\text { B100 ethyl } \\
\text { soybean } \\
\text { biodiesel }\end{array}$ \\
\hline $\begin{array}{l}\text { Sulfur tenor } \\
(\mathrm{mg} / \mathrm{kg})\end{array}$ & 6.9 & 5.6 & 4.7 & 5.3 & 4.1 \\
$\begin{array}{l}\text { Carbon tenor } \\
(\% \mathrm{~m} / \mathrm{m})\end{array}$ & 83.9 & 78.9 & 74.1 & 74.9 & 74.1 \\
$\begin{array}{l}\text { Hydrogen tenor } \\
(\% \mathrm{~m} / \mathrm{m})\end{array}$ & 14.1 & 13.2 & 12.2 & 12.7 & 12.3 \\
$\begin{array}{l}\text { Nitrogen tenor } \\
(\% \mathrm{~m} / \mathrm{m})\end{array}$ & 0.128 & 0.066 & 0.052 & 0.087 & 0.077 \\
$\begin{array}{l}\text { Lower heating } \\
\text { value }(\mathrm{kJ} / \mathrm{kg})\end{array}$ & 41956 & 39316 & 36835 & 39821 & 36727 \\
$\begin{array}{l}\text { Higher heating } \\
\text { value }(\mathrm{kJ} / \mathrm{kg})\end{array}$ & 44937 & 42161 & 39465 & 42557 & 39381 \\
\hline
\end{tabular}




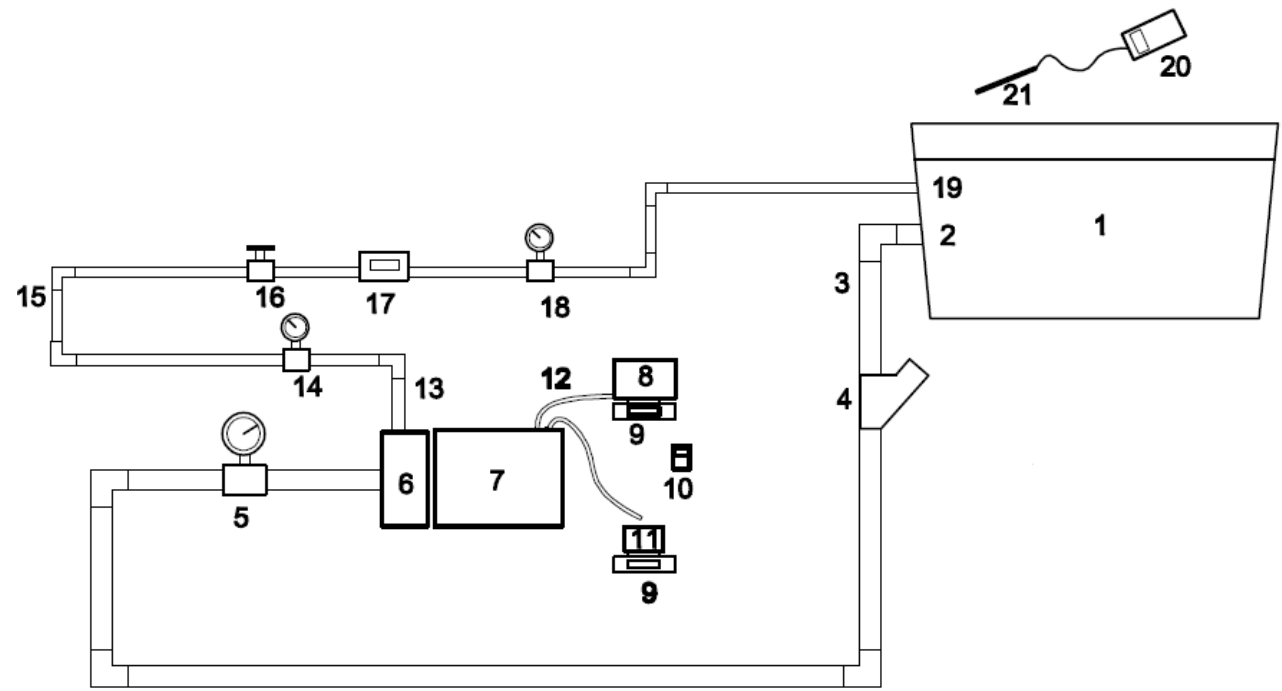

1 - reservoir; 2 - suction; 3 - tube of 2"; 4 - Y filter; 5 - pressure gauge in the suction; 6 - centrifugal pump; 7 - diesel engine; 8 - fuel reservoir; 9 - digital scale; 10 - room temperature meter; 11 - reservoir of returning fuel; 12 - hoses; 13 - discharge tube of 2"; 14 - pressure gauge; 15 - tube of 1.5"; 16 - globe valve of 1.5"; 17 - flow meter; 18 pressure gauge; 19 - discharge; 20 - temperature meter; 21 - sensor

Fig. 1 Experimental apparatus

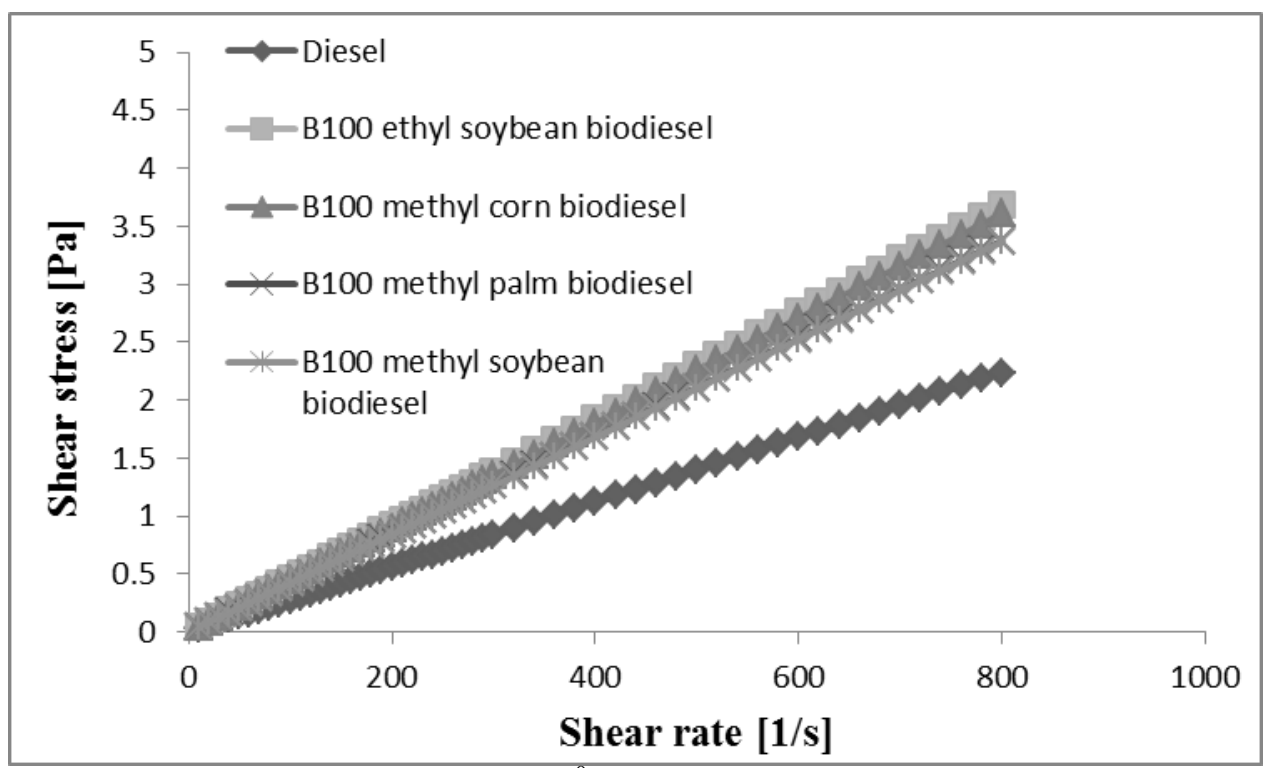

Fig. 2 Flow curve at $40^{\circ} \mathrm{C}$ for diesel and B100 biodiesels 
Use of Soybean, Corn and Palm Biodiesel in a Centrifugal Pump Driven by a Diesel Engine: Performance and Emissions Analysis

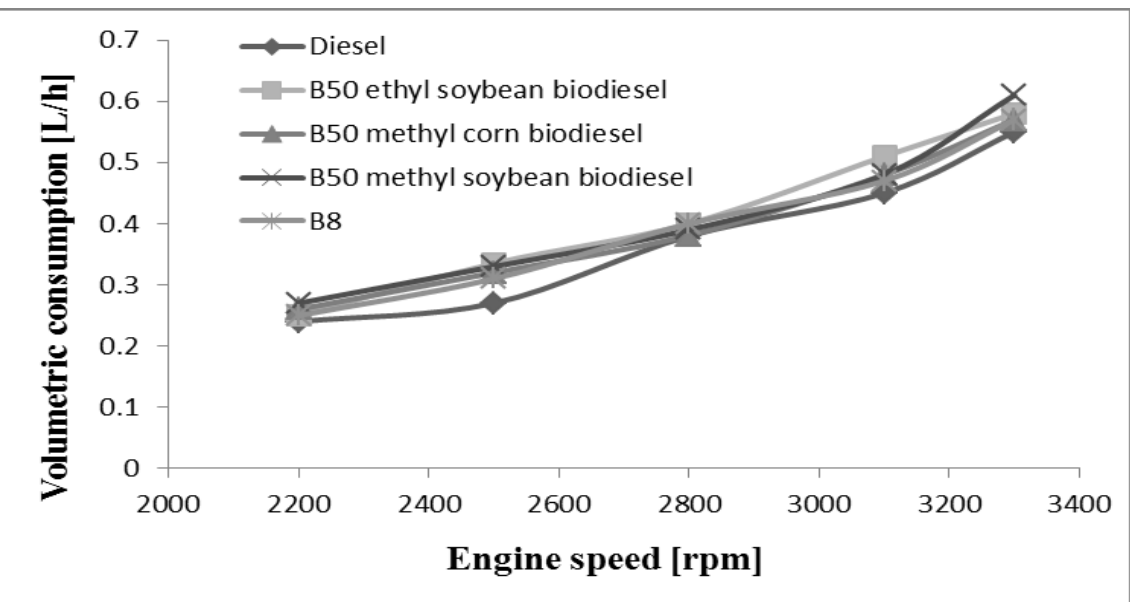

Fig. 3 Volumetric consumption $x$ Engine speed for diesel, B8 and B50 biodiesels

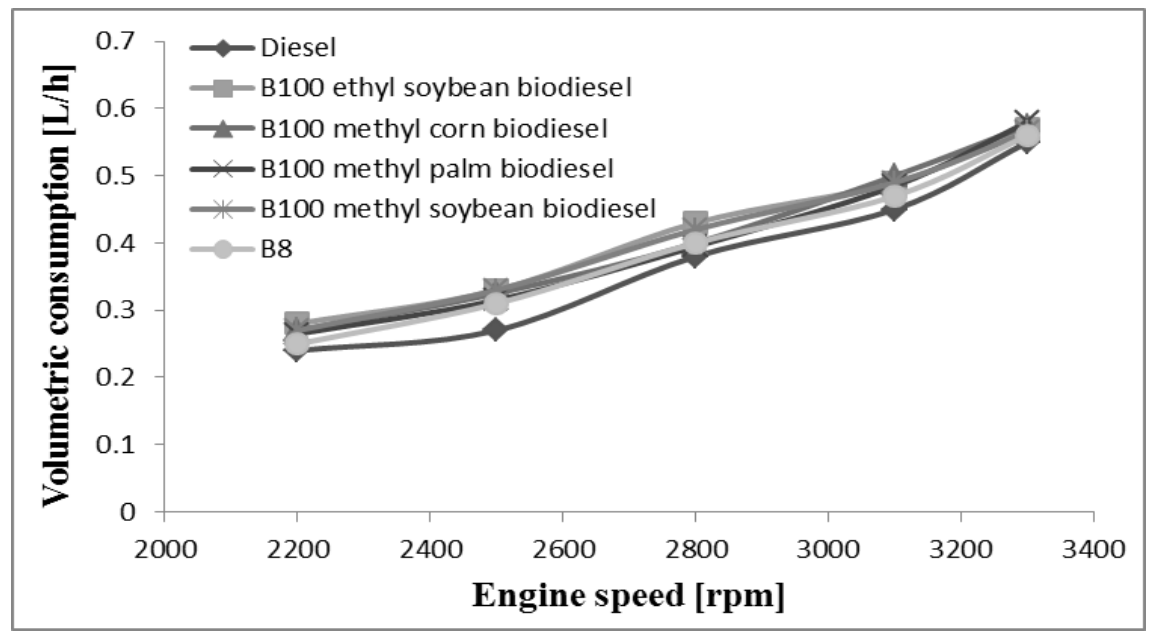

Fig. 4 Volumetric consumption $x$ Engine speed for diesel, B8 and B100 biodiesels

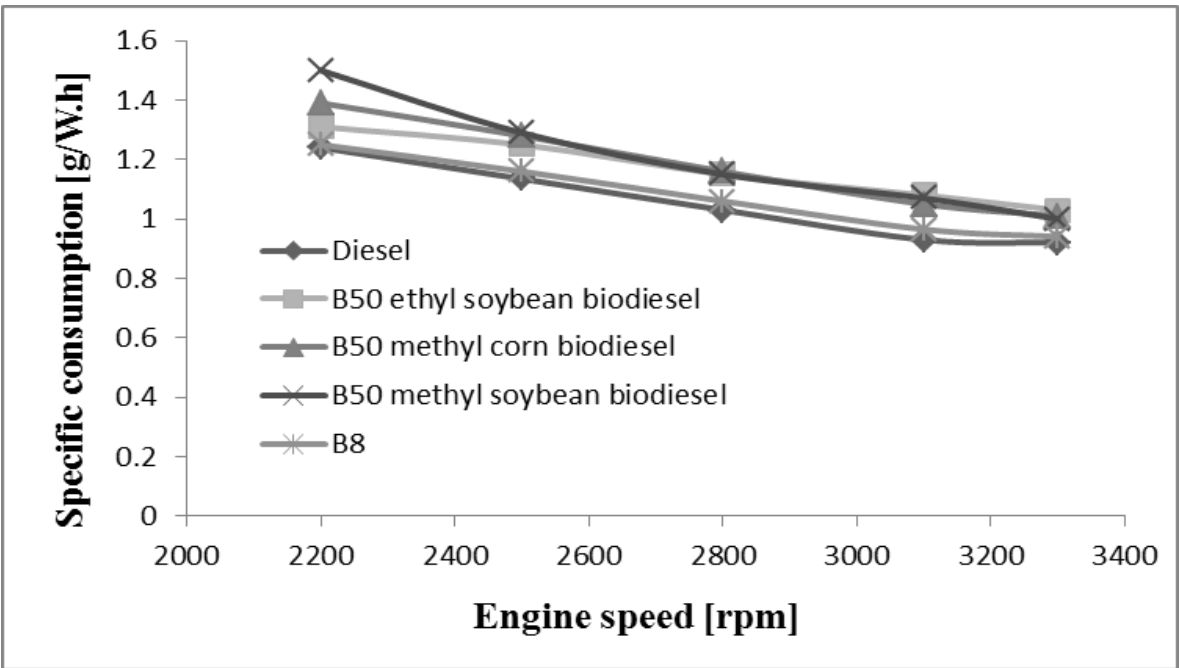

Fig. 5 Specific consumption x Engine speed for diesel, B8 and B50 biodiesels 
Use of Soybean, Corn and Palm Biodiesel in a Centrifugal Pump Driven by a Diesel Engine: Performance and Emissions Analysis

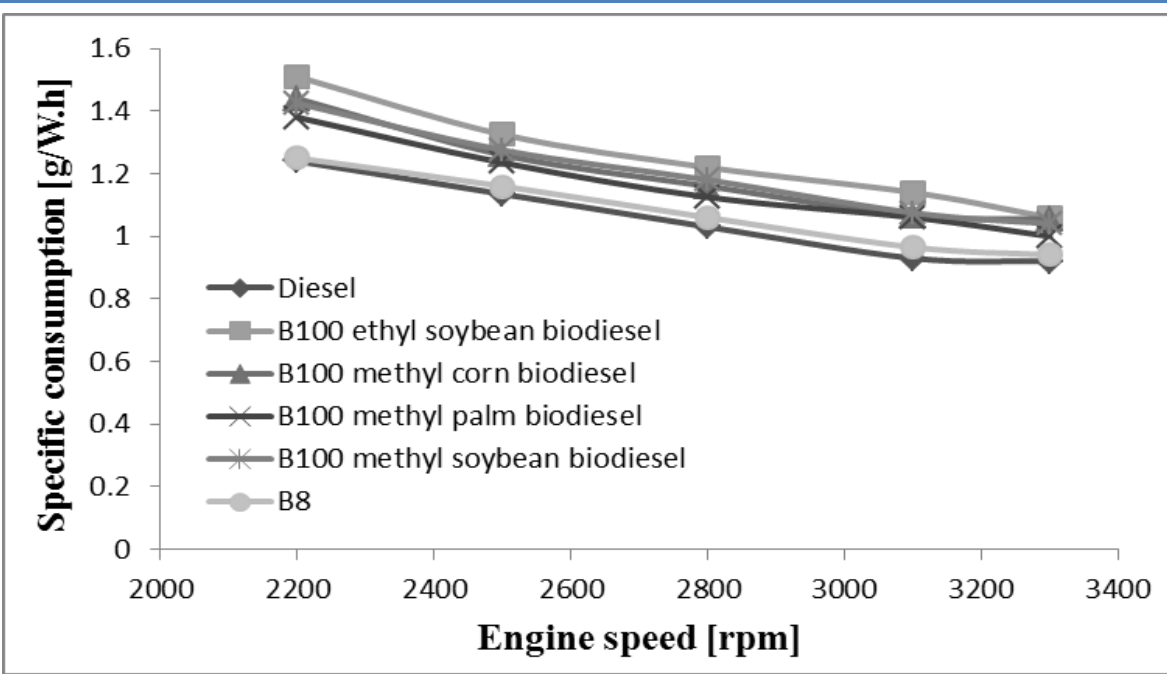

Fig. 6 Specific consumption x Engine speed for diesel, B8 and B100 biodiesels

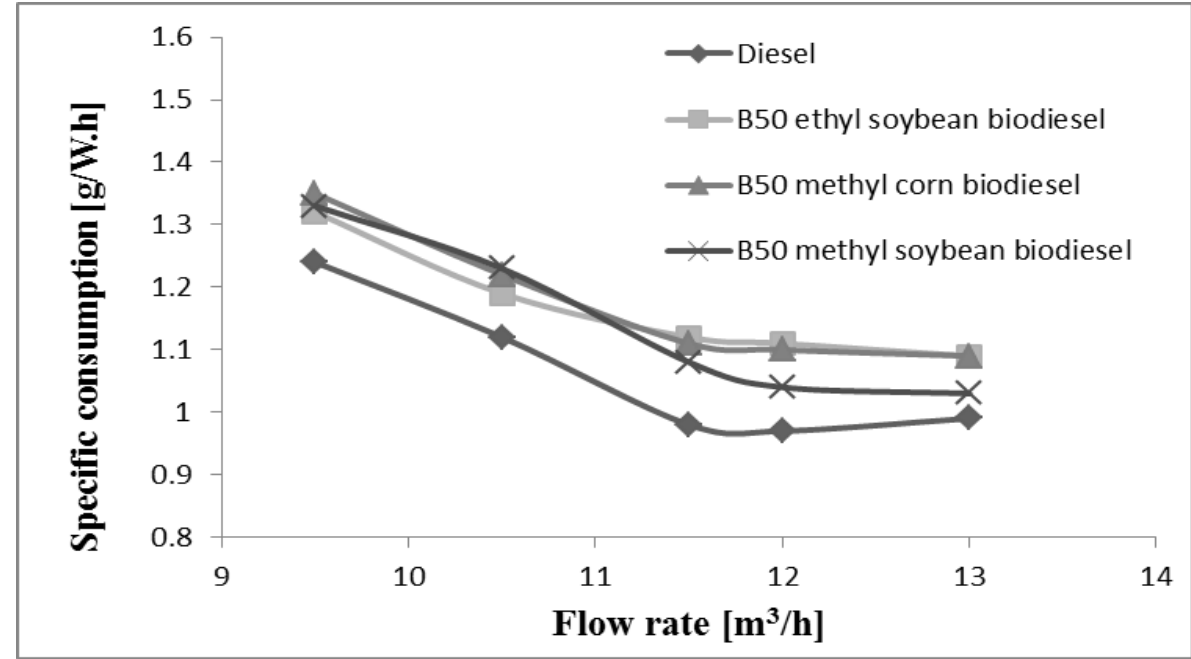

Fig. 7 Specific consumption $x$ Flow rate for diesel and B50 biodiesels

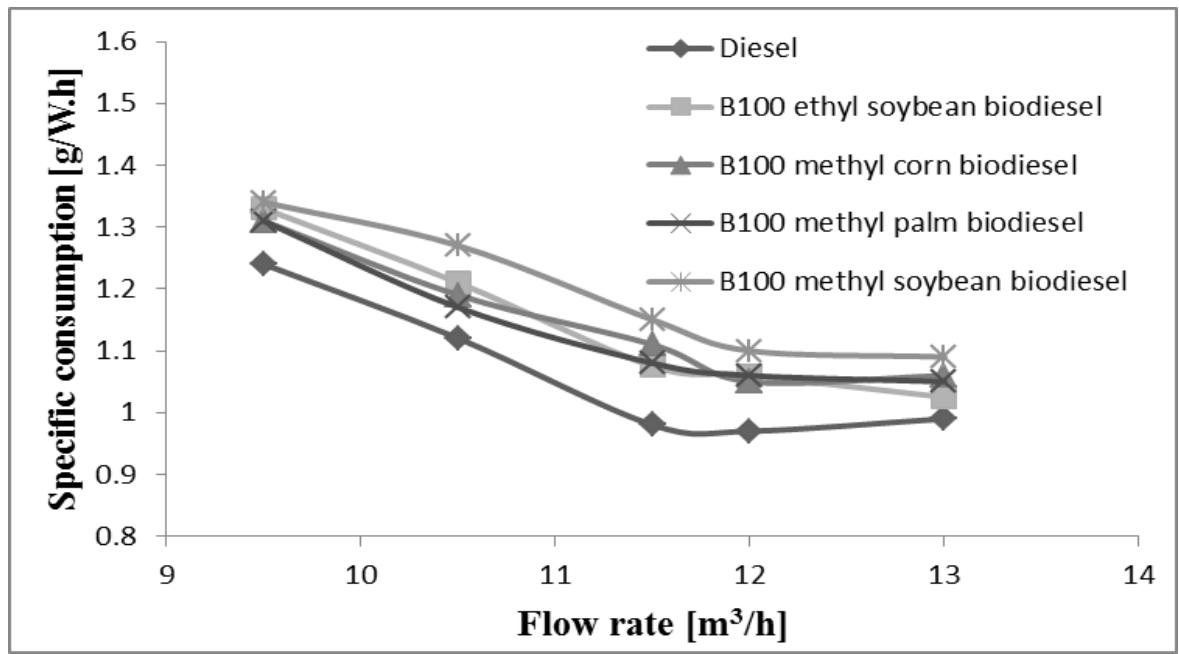

Fig. 8 Specific consumption x Flow rate for diesel and B100 biodiesels 
Use of Soybean, Corn and Palm Biodiesel in a Centrifugal Pump Driven by a Diesel Engine: Performance and Emissions Analysis

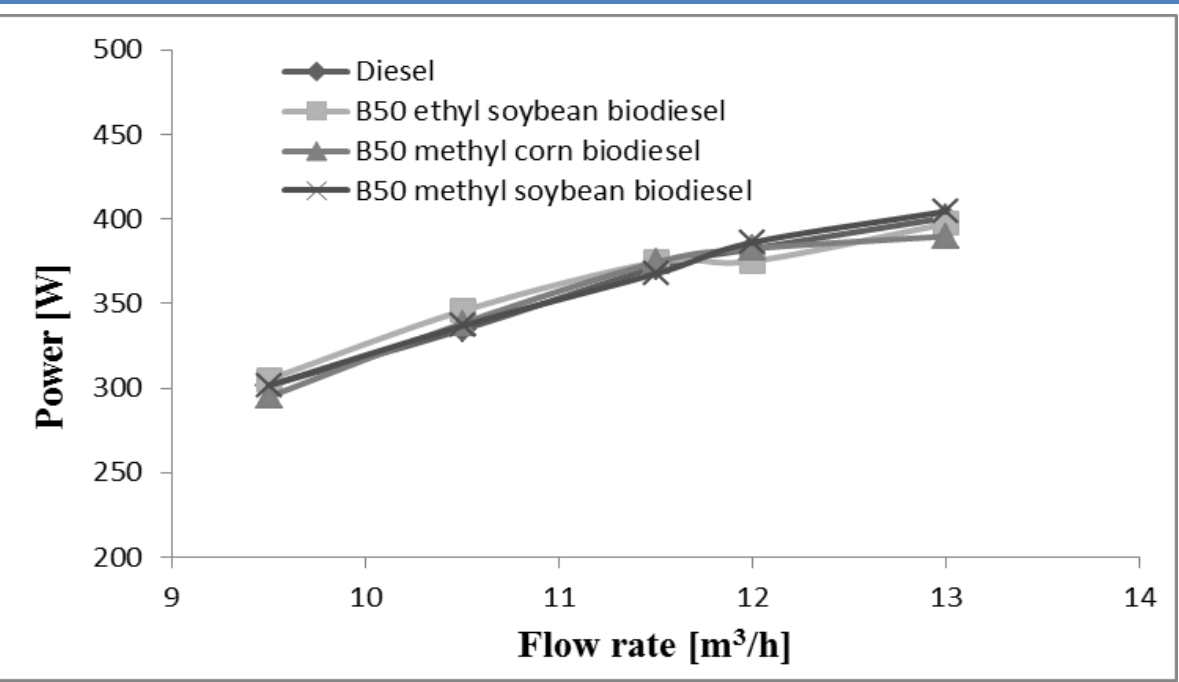

Fig. 9 Power x Flow rate for diesel and B50 biodiesels

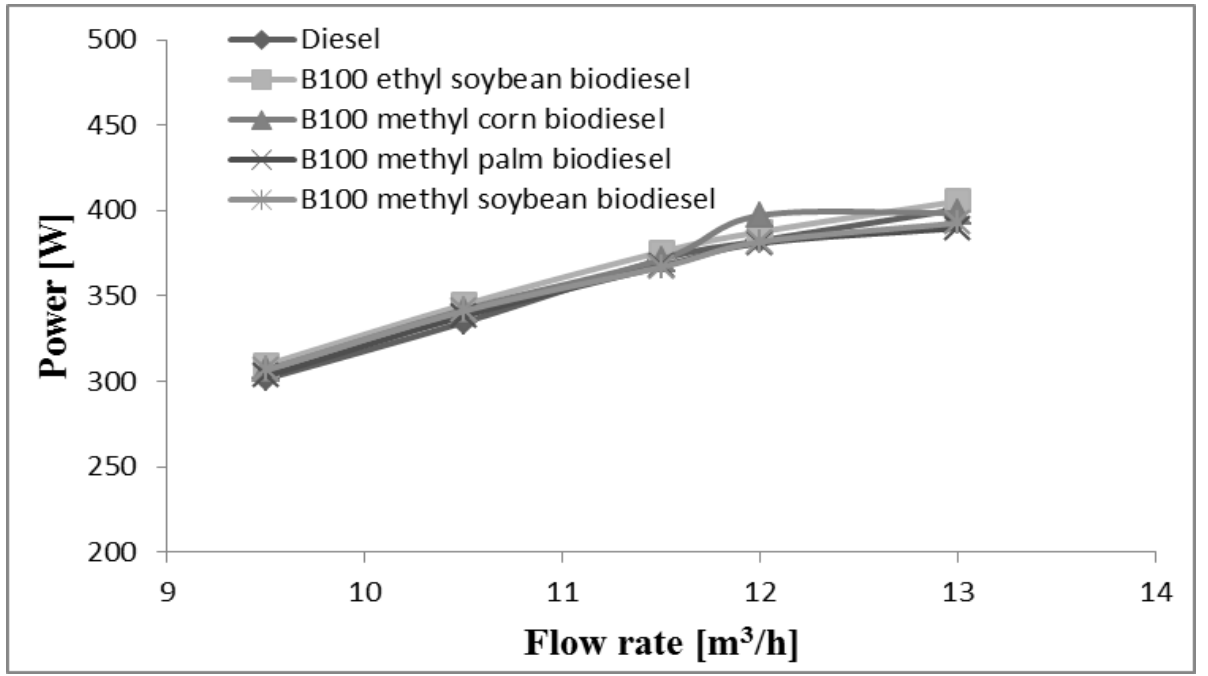

Fig. 10 Power $x$ Flow rate for diesel and B100 biodiesels

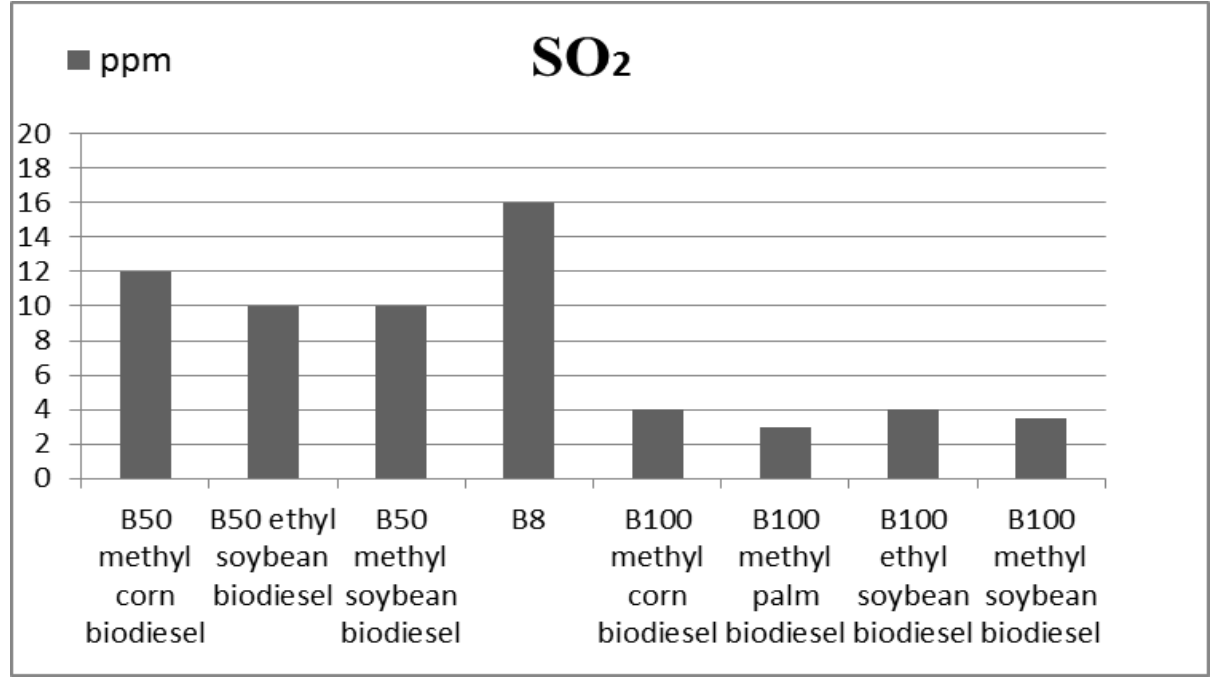

Fig. $11 \mathrm{SO}_{2}$ emissions 
Use of Soybean, Corn and Palm Biodiesel in a Centrifugal Pump Driven by a Diesel Engine: Performance and Emissions Analysis

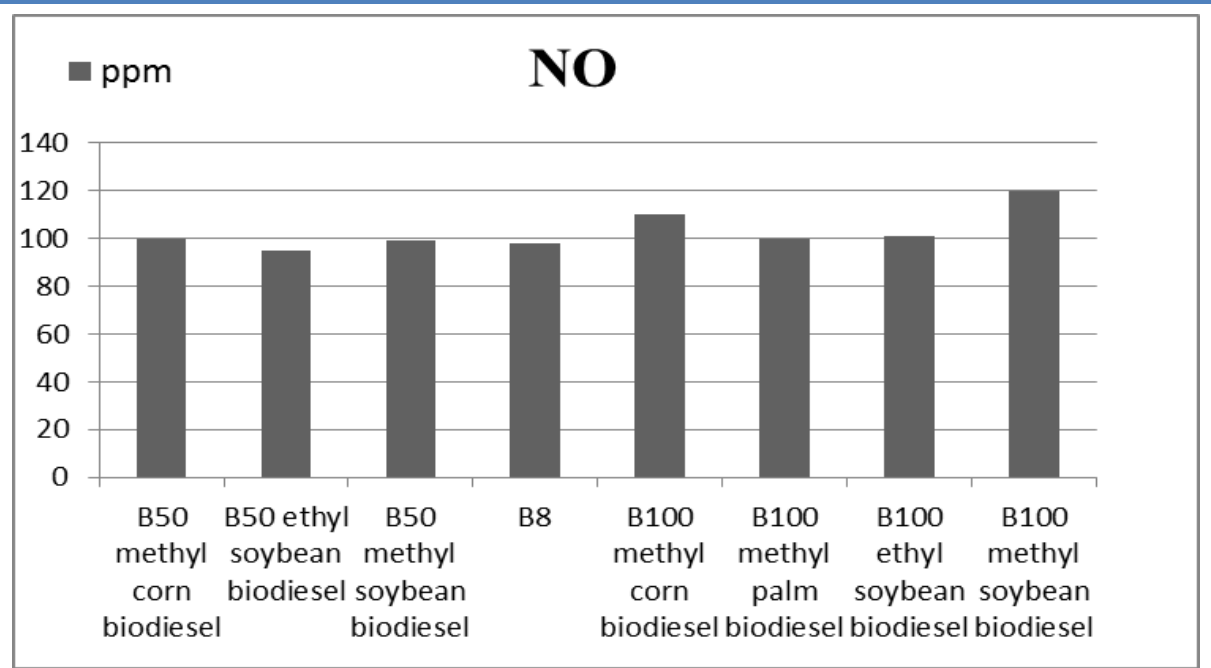

Fig. 12 NO emissions

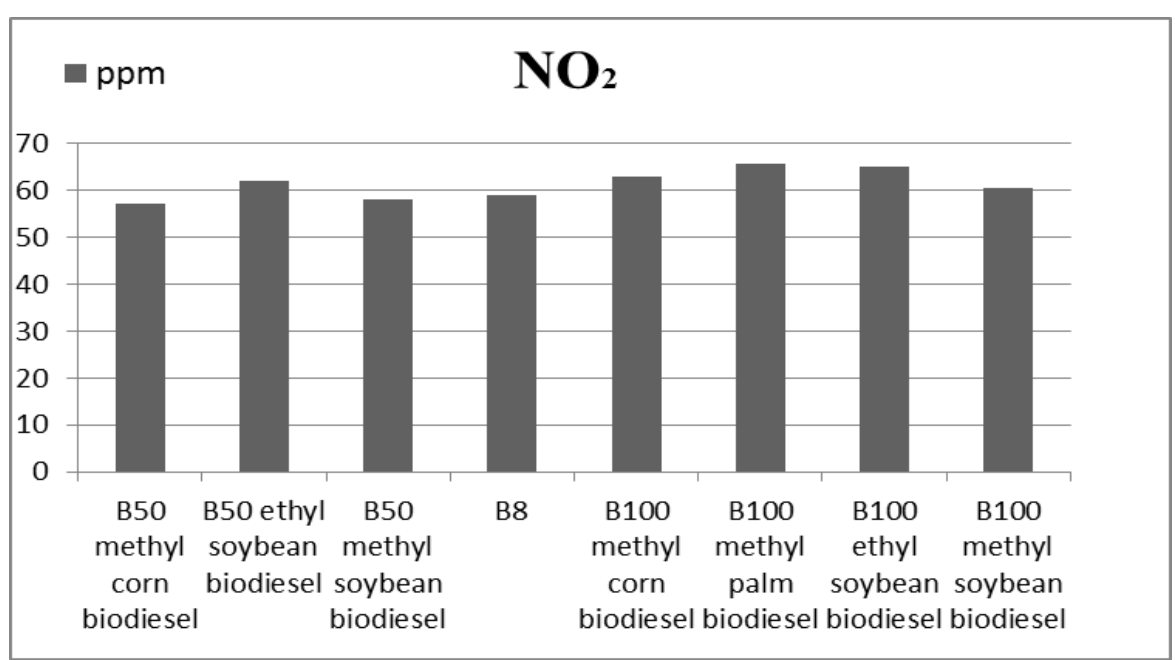

Fig. $13 \mathrm{NO}_{2}$ emissions

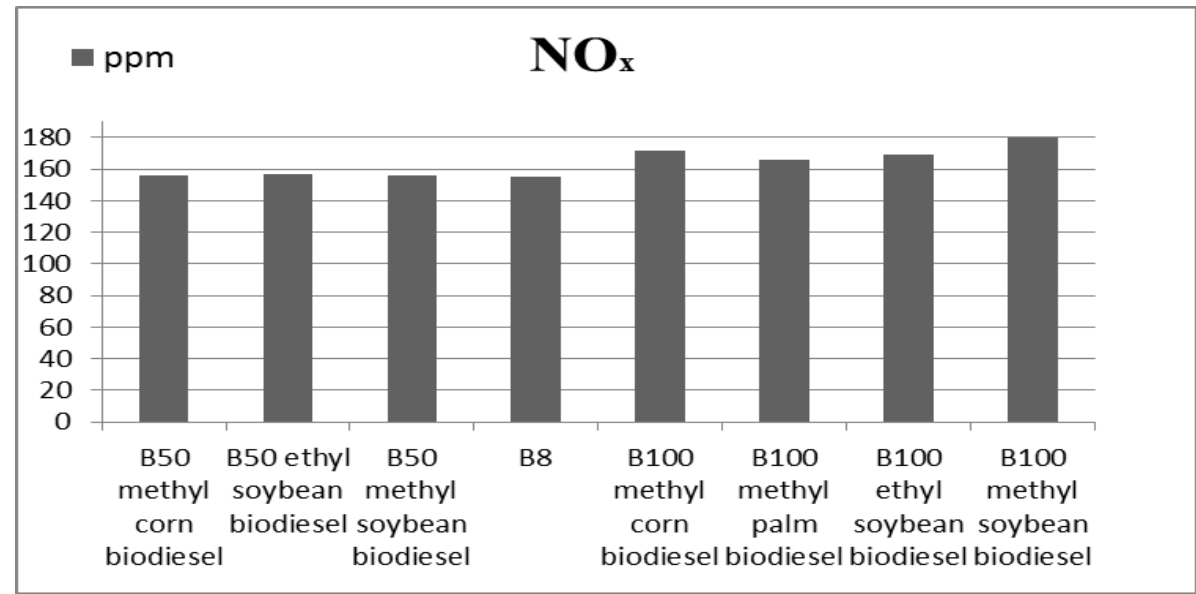

Fig. $14 \mathrm{NO}_{\mathrm{x}}$ emissions 
Use of Soybean, Corn and Palm Biodiesel in a Centrifugal Pump Driven by a Diesel Engine: Performance and Emissions Analysis

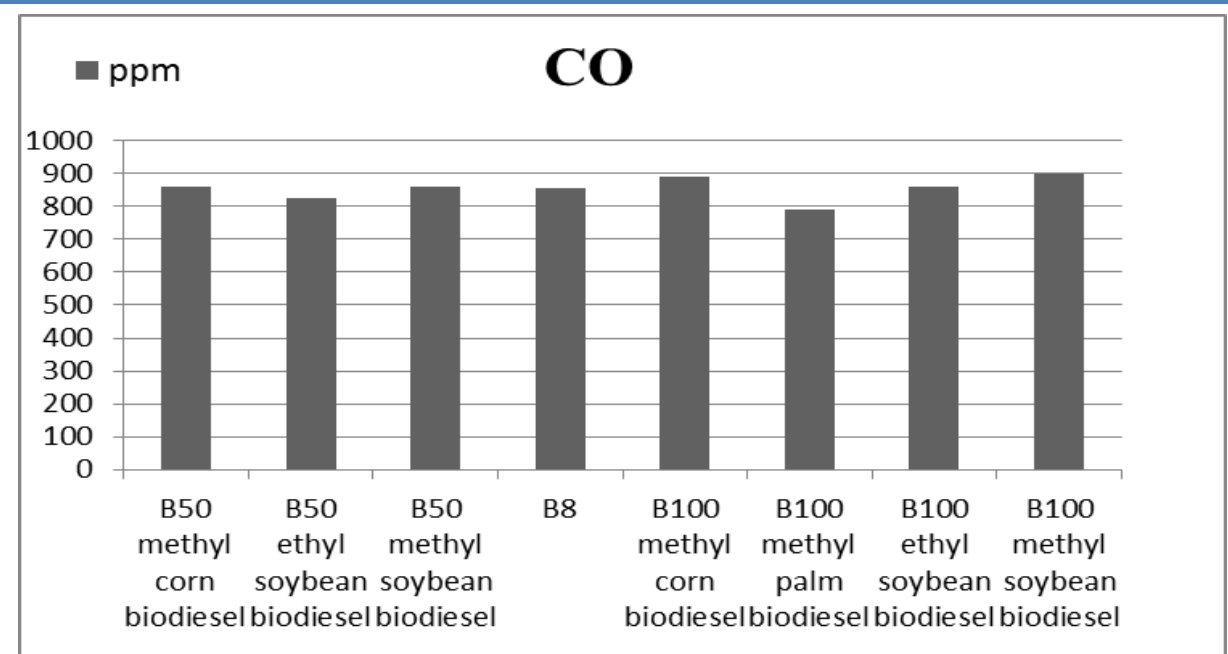

Fig. $15 \mathrm{CO}$ emissions

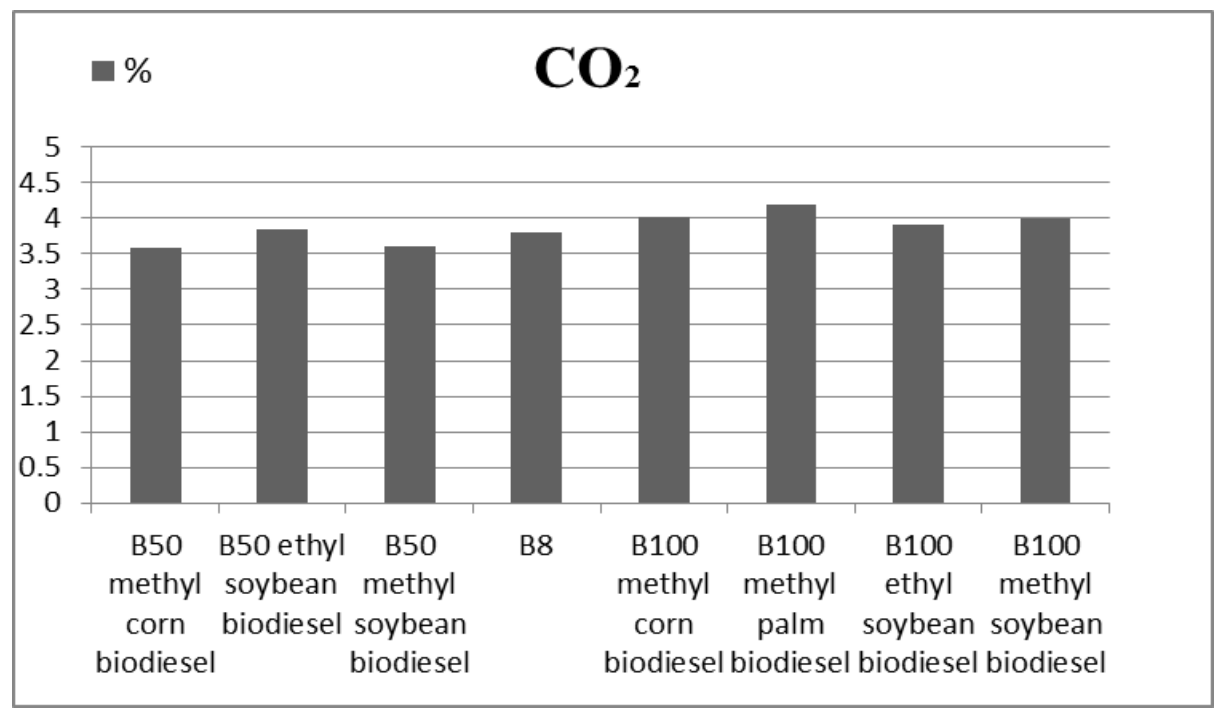

Fig. $16 \mathrm{CO}_{2}$ emissions 